\title{
Degradasi Integritas Kepemimpinan dan Upaya Preventif ${ }^{1}$
}

\section{Arif Yupiter Gulo ${ }^{2}$}

Kepemimpinan adalah proses mempengaruhi atau memberi contoh oleh pemimpin kepada pengikutnya dalam upaya mencapai tujuan organisasi (Wikipedia). Yakob Tomatala mengatakan, kepemimpinan ialah suatu proses terencana yang dinamis melalui periode waktu dalam situasi (suatu atau berbagai situasi yang di dalamnya pemimpin menggunakan, prilaku (Pola/gaya) kepemimpinan yang khusus dan sarana serta prasarana kepemimpinan/sumber untuk memimpin menggerakkan dan mempengaruhi bawahan (Pengikut-pengikut) guna melaksanakan tugas/pekerjaan (menyelesaikan tugas) ke arah (dalam upaya pencapaian) tujuan yang menguntungkan (membawa keuntungan yang timbal balik) bagi pemimpin dan bawahan serta lingkungan sosial di mana mereka hidup. Ironisnya, observasi penulis menemukan degradasi dalam kepemimpinan Kristen dewasa ini. Apa sesungguhnya degradasi itu? Langka kita menemukan kepemimpinan yang memiliki future planning yang ada adalah bagaimana dapat menyelamatkan diri semasih menjadi pemimpin. Itu artinya tidak ada program yang eksplisit dapat memajukan organisasi di mana dia memimpin. Sering orang berkata "Ilmu selamat". Selain itu, jangankan tetap bertahan tentang pencapaian yang ada, justru yang terjadi adalah kemunduran dalam menata secara organsasi dan juga menata SDM-nya. Orang yang ditempatkan tidak sesuai dengan keahliannya. Ada istilah yang lebih tepat, siapa yang tidak mengkritik maka menjadi teman, maka itu yang ditempatkan walau ilmunya dalam bagian itu tidak setajam silet (istilah saya). Dengan demikian maka terjadi kekeringan integritas. Maka diragukan integritasnya soal kejururannya dalam mewujudkan visi-Misinya. Visi-Misinya hanya sebatas coretan tinta pena di atas kertas putih dengan rangkaian kata yang menggoda dan mempesona. Kemudian dengan gagahnya membawa kertas di atas podium dengan membacanya dengan menebarkan senyum untuk menghinopsis yang mendengar supaya pendengar lewat kepala tidak geleng-geleng tetapi mengangguk-ngangguk. Mengapa hal ini terjadi? Kembali mereview panggilan sebagai pemimpin. Kita ditempatkan Tuhan dalam jabatan tertentu untuk memimpin. Jadi, pola dan sikap kepemimpinan yang teladani adalah berdasarkan dengan Alkitab bukan dengan bisikan gelar, ijazah akademik atau orang yang ada di sekitar yang bisikannya penuh

\footnotetext{
${ }^{1}$ Sumber judul dari Teman dan terinspirasi untuk menulis, tulisan yang sederhana.

${ }^{2}$ Pendeta BNKP dan Dosen STT Pokok Anggur Jakarta
} 
dengan kepentingannya. Kemudian, bagaimana caranya supaya mendapatkan pemulihan dan kebangkitan kepemimpinan menjadi efektif?

Upaya preventif yang ditempuh adalah memimpin dengan hati bukan dengan kepala. Ken Blanchard dan Philip Hodges mengatakan, perjalanan kepemimpinan yang melayani mulai dari hati dengan motivasi dan niat. Kemudian perjalanan itu berlanjut melalui kepala, yang menekankan system kepercayaan pemimpin dan perspektifnya tentang peran seorang pemimpin. (Blanchard dan Philip Hodges: hal 109). Mengapa hati? Amsal 18:15 menyatakan bahwa Hati orang berpengertian memperoleh pengetahuan. Inilah landasan Alkitabiah terhadap kepemimpinan. Anda sekarang pakai hati atau kepala? Ubah pakai hati. Memimpin sebagai Hamba. Mengapa Hamba? Yesus telah menegaskan "Dan barangsiapa ingin menjadi yang terkemuka di antara kamu, hendaklah ia menjadi hamba untuk semuanya (Markus 10:44). Memimpin dengan menyangkal diri. Jabatan dan harta serta gelar akademik hanya instrument untuk memimpin namun bukan satu-satunya untuk memajukaan. Itu sebabnya tidak perlu ditonjolkan dengan menganggap remeh orang lain. Sejatinya, menyangkal diri. Filipi 2:7 menyatakan, Melainkan telah mengosongkan diri-Nya sendiri, dan mengambil rupa seorang hamba, dan menjadi sama dengan manusia. Anda masih anggap diri hebat? Tatap ke atas lihatlah salib itu. Orang yang ada di salib itu orang hebat yang menyerahkan diri-Nya untuk menebus dosa umat manusia.

Ketika pola dan sikap tersebut maka terjadi perubahan signifikan untuk dapat mempengaruhi orang lain guna untuk memajukan organisasi. Jika sudah maju maka yang menikmati adalah kita dan anak cucu kita ke depan. Mau seperti itu? Ubahlah sikap anda, Malu? Orang yang terus menganggap diri hebat pasti sukar bagi dirinya untuk berubah. Orang yang tidak merendahkan diri sukar bagi dirinya untuk mengakui kekurangan dan kelemahannya. Merendahkan dirilah dengan menepuk dada bahwa saya adalah ENONI. Bahkan bukan dengan menepuk dada bahwa saya adalah ENONI dengan kamusflase tetapi dari penyadaran diri yang sungguh-sungguh.

\section{Grand Sutera: Kuta Bumi.}

Coretan pena di atas kertas disampingnya ada gelas kopi yang masih berisi. 